\title{
FUNDAMENTAL AND MANAGEMENT
} NURSING JOURNAL

\author{
Vol. 4, No. 1, April 2021
}

Laman jurnal: https://e-journal.unair.ac.id/FMNI

http://dx.doi.org/ 10.20473/fmnj.v4i1.21587

Original Research

\section{The Correlation Between Infection Diseases History and Nutritional Status in Toddler}

\author{
Ervi Suminar* and Ach. Riyanto Wibowo \\ 1Universitas Muhammadiyah Gresik, Gresik, East Java, Indonesia \\ ${ }^{2}$ Stikes Insan Unggul Surabaya, East Java, Indonesia
}

\section{ARTICLE HISTORY}

Received: August, 252020

Revised : November, 142020

Accepted: January, 132021

Available online: April, 12021

\section{KEYWORDS}

infection; nutritional status; toddler

\section{CORRESPONDING AUTHOR}

Ervi Suminar ervi.suminar@umg.ac.id

Universitas Muhammadiyah Gresik, Gresik, East Java, Indonesia

Cite this as:

\begin{abstract}
Introduction: Infection is one of the diseases that often occurs in children under five. Malnutrition is one of the causes of infection. Malnutrition and poor nutrition reduce body resistance to various diseases, especially infectious diseases. The purpose of this study was to determine the relationship between the infectious diseases history and children under five nutritional statuses at Integrated Healthcare Center (Posyandu) Sumur Nangka, Modung District, Bangkalan Regency.

Method: This research was observational with cross sectional design. The independent variable is a history of infectious disease and the dependent variable is nutritional status in children under five. The population of this research was all children under five at Posyandu Sumur Nangka, Suwaan Village, Modung Subdistrict, with a total of 45 children with a sample size of 32 children who were selected by simple random sampling. Data collection using a questionnaire. Test data analysis using the Lambda correlation test.

Results: The study results showed that $24(75.0 \%)$ children had infectious diseases history and $8(25.0 \%)$ children did not have. Eight $(25.0 \%)$ children had good nutritional status, 22 $(68.8 \%)$ children had poor nutritional status, and $2(6.2 \%)$ children had excess nutritional status. Lamda's statistical test showed that the value of $\mathrm{p}(0.003)<\alpha(0.05)$ means that $\mathrm{H} 0$ is rejected and $\mathrm{H} 1$ is accepted. There was a significant relationship between the infectious diseases' history and the nutritional status of children under five.

Conclusion: The infection history affects the nutritional status of children under five. Parents must monitor the health of children under five and the nutritional status of toddlers actively by monitoring nutritional intake and weighing toddlers periodically.
\end{abstract}

Suminar, E., \& Wibowo, A.R. (2021). The Correlation Between Infection Diseases History and Nutritional Status in Toddler. Fundam Manaj. Nurs. J. 4(1), 18-22. doi.org/10.20473/fmnj.v4i1.215587

\section{INTRODUCTION}

Nutritional problems have spacious dimensions, not only health problems but also social, economic, cultural, parenting, educational, and environmental problems. The emergence of nutritional problems was triggered by various factors which differ between regions or groups of people. The root of the problem differs between the age groups of under five. Malnutrition condition can reduce the body's resistance to various diseases, especially infectious diseases. The condition could interfere the physical, mental, and brain tissue growth and development, which could lead to quality reduction of Indonesia's human resources.

According to the World Health Organization (WHO 2013), 17\% or 98 million children under five years in developing countries experienced malnutrition (low body weight according to age based on WHO standards). In East Java, the prevalence of 
malnutrition children under five is $17.4 \%$. This condition implied that the national target of nutrition improvement in 2015 has not reached, that the prevalence of malnourished children under five should be less than $16 \%$ and according to the 2015 MDGs target should be less than 16.5. \%. Of the 38 districts in East Java, there are 7 districts that have not reached the national target (16\%): Jember, Probolinggo, Nganjuk, Bangkalan, Sampang, Pamekasan and Sumenep (Rikesdas, 2015).

The number of children experience malnutrition in Bangkalan was yearly incline. In 2010, there were 284 malnutrition children, in 2011 there were 292 malnourished toddlers, in 2012 there were 294 malnourished children, while in 2013 was 298 malnutrition children, and in 2014, 323 malnutrition children were found (Health Profile of Bangkalan Regency, 2014). Based on a preliminary study conducted on 10 toddlers at Posyandu Sumur Nangka, Suwaan Village, Modung District, Bangkalan Regency, using the body weight per age indicator obtained 2 malnourished children, 4 malnourished children, 2 good nourished children, 2 excess nourished children. Based on the research location, it was found that $20 \%$ malnutrition, $40 \%$ poor nutrition, $20 \%$ good nutrition, $20 \%$ over nutrition.

Factors affecting the nutritional status of children under five include the history of infectious diseases. Infectious diseases can worsen the nutritional condition of children under five. Poor nutrition conditions made toddlers susceptible to infectious diseases. Infectious diseases with nutritional status had a reciprocal relationship.

Infection diseases in children under five causes a decrease in the nutritional status. The nutritional status of children under five is affected by two main factors, namely the amount of food intake and the health condition concerned. Lack of food consumption, especially energy and protein in a certain period of time, will cause the child's weight to decrease, so that the immune system decreases and is prone to infectious diseases.

The Nutrition improvement effort is encouraged, with more emphasis on the parents' participation in maintaining the nutritional status of toddlers by providing a balanced diet and completing immunization. This study aimed to know the relationship of infectious disease history to the nutritional status of children under five at Sumur Nangka Health Center in 2018.

\section{METHODS}

In this study the population was all toddlers at the Sumur Nangka Posyandu, Suwaan Village, Modung District, Bangkalan Regency, as many as 45 toddlers. The sample in the study was children underfives at Posyandu Sumur Nangka, Suwaan Village, Modung District, Bangkalan Regency who met the criteria as many as 32 toddlers. The sampling technique is a method of taking a number of samples in order to represent the number and characteristics of the population (Sudibyo and Rustika, 2013).

This study used simple random sampling, namely selecting samples in this way is the simplest type of probability. To achieve this sampling, each element is randomly selected. If the sampling frame is small, then it can be written on a piece of paper, put in a box, stirred, and taken randomly after everything is collected (Nursalam, 2011). The tool used in data collection was the Midwife's Main Book.

\section{RESULTS}

Table 1. The distribution of toddler characteristics based on age, sex, education, occupation levels, infectious diseases history, nutritional status

\begin{tabular}{|c|c|c|}
\hline Characteristic & $\mathrm{N}$ & $(\%)$ \\
\hline \multicolumn{3}{|l|}{ Age } \\
\hline 1-2 Year & 7 & 21,9 \\
\hline 3-4 Year & 25 & 78,1 \\
\hline Total & 32 & 100.0 \\
\hline \multicolumn{3}{|l|}{ Sex } \\
\hline Male & 17 & 53,1 \\
\hline Female & 15 & 46,9 \\
\hline Total & 32 & 100.0 \\
\hline \multicolumn{3}{|l|}{ Education } \\
\hline Elementary school & 10 & 31,2 \\
\hline Junior high school & 7 & 21,9 \\
\hline Senior high school & 13 & 40,6 \\
\hline Bachelor degree & 2 & 4,2 \\
\hline Total & 32 & 100 \\
\hline \multicolumn{3}{|l|}{ Job } \\
\hline Enterpreneur & 10 & 31,2 \\
\hline Farmer & 20 & 62,5 \\
\hline $\begin{array}{l}\text { Government } \\
\text { employees }\end{array}$ & 2 & 6,2 \\
\hline Total & 32 & 100,0 \\
\hline $\begin{array}{l}\text { Infection disease history } \\
\text { Yes }\end{array}$ & 24 & $75,0 \%$ \\
\hline No & 8 & $25,0 \%$ \\
\hline Total & 32 & $100 \%$ \\
\hline Nutritional status & $\mathrm{n}$ & $\%$ \\
\hline Poor & 22 & $68,8 ? \%$ \\
\hline Good & 8 & $25,0 \%$ \\
\hline Excess & 2 & $6,2 \%$ \\
\hline Total & 32 & $100 \%$ \\
\hline
\end{tabular}

Based on table 1, it can be concluded that of the 32 respondents, most of respondents were 3-4 years old, as many as 25 toddlers (78.1\%) and it was known that the sex of toddlers was mostly male, namely 17 toddlers (53.1\%). The job type of mothers is mostly farmers, as many as 20 people $(62.5 \%)$. Almost all children under five at the Sumur Nangka Posyandu have a history of infectious diseases during the last 13 months, as many as 24 children (75.0\%). Most of the nutritional status of children under five at the Sumur Nangka Posyandu had poor nutritional status (68.8\%). 
Table 5. Cross-tabulation of Infection Disease History with Nutritional Status in Toddlers

\begin{tabular}{|c|c|c|c|c|c|c|}
\hline \multirow{3}{*}{$\begin{array}{l}\text { Nutritional } \\
\text { status of pre- } \\
\text { school } \\
\text { children } \\
\text { (body } \\
\text { weight/Age) }\end{array}$} & \multicolumn{4}{|c|}{ Infection disease history } & \multicolumn{2}{|c|}{ Total } \\
\hline & \multicolumn{2}{|c|}{ Iya } & \multicolumn{2}{|c|}{ Tidak } & \multirow[b]{2}{*}{$\mathrm{N}$} & \multirow[b]{2}{*}{$\%$} \\
\hline & $\mathrm{N}$ & $\%$ & $\mathrm{~N}$ & $\%$ & & \\
\hline Poor & 22 & 91,6 & 0 & 0 & 22 & 100 \\
\hline Good & 0 & 0 & 8 & 100 & 8 & 100 \\
\hline Excess & 2 & 8,3 & 0 & 0 & 2 & 100 \\
\hline Total & 24 & 99,9 & 8 & 37,5 & 32 & 100 \\
\hline
\end{tabular}

Based on table 5 , it shows that of the 22 toddlers who experience malnutrition as many as 22 children under five.

\section{DISCUSSION}

Thirty-two children under five at the Sumur Nangka Posyandu, Suwaan Village, Modung District, almost all of them who had a history of infectious diseases in the last three months (75.0\%) and a small proportion who did not have $(25.0 \%)$. Alania (2013) stated that preschoolers are more susceptible from infectious diseases. This could be caused by children behaviour that have started to play actively which make them easily contaminated by feces. Pudjiadi (2010) explained that children aged 3-5 years have started the habit of buying snack food which is usually not kept clean, both in processing and serving it, so it is very easy to be contaminated by germs that can cause infection diseases such as diarrhea, spasms, gastritis, malaria, and measles.

Irawati (2007) explained that the main factors cause infection diseases include bacteria, viruses, parasites, and fungi. Bacteria are one of the main factors affecting the infection diseases history that often occur in toddlers.

Previous research conducted in the study setting showed that upper respiratory tract infection (ISPA) and diarrhea affected the infection diseases history. Many children aged 1-4 years had infection diseases history in the last three months. Diarrhea was diseases that experienced by most children aged 1-2 years. Diarrhea caused by bacteria. Children aged 1-2 is susceptible to exposed to infectious diseases.

Meanwhile, children aged 3-4 years in the study setting have upper respiratory tract infection (ISPA) infection history which is also caused by bacteria. Infectious diseases will cause nutritional problems in several ways, namely vomiting and diarrhea. In addition, infectious diseases can reduce appetite. The incidence of infection is related to poor hygiene and environmental sanitation and children often consume or buy less hygienic food at school or when playing at home without parental supervision.

All diseases that have been experienced by children are due to bacterial factors caused by less hygienic food with a history of infectious diseases. This is what makes the nutritional status of children disrupted which does not support a better nutritional status.

Parents' role is important in monitoring children's health, especially the food consumed by children so that children can avoid infectious diseases, one of which is diarrhea. Therefore, parents should increase supervision of the food consumed by children.

Thirty-two toddlers at the Sumur Nangka Posyandu, Suwaan Village, Modung District, had good nutritional status, namely 8 children (25.0\%), 2 children $(6.2 \%)$ had excess nutritional status, 22 children $(68.8 \%)$ had poor nutritional status. Sediaoetama (2010) stated that nutritional status is the state of the balance body between the nutrients that enter the body and its utilization. Nutritional status is an expression of a state of balance in the form of certain variables, or the manifestation of nutriturie in the form of certain variables, for example: Endemic goiter is a state of imbalance in the intake and expenditure of iodine in the body (Supariasa, 2016).

Nutritional status is influenced by food consumption and health state. Food consumption is influenced by nutrients in food, family feeding programs, eating habits, health care, family purchasing power, physical and social environment (Supariasa, et al, 2012)

An individual nutritional status considered to be good if there is a balance between physical development and intellectual mental development. Nutritional status is influenced by two factors, namely food consumption and health. Food consumption is influenced by nutrients in food, family feeding programs, eating habits, health care, family purchasing power, physical environment and problems (Proverawati \& Asfuah, 2010).

This result was in line with prior research conducted by Setiaji (2012) which stated that housewive mothers have more opportunities to educate, care for, control nutritional intake and children's diet so that children have good nutritional status and children can grow and develop well. This is indicated by the results of the research as much as $34.6 \%$ of mothers' work as housewives and $84.6 \%$ of children have good nutritional status

Parents' education does not affect nutritional status. The results of the study in table 5.3 shows that the level of education of the parents of children under five at Posyandu Sumur Nangka, Suwaan Village, Modung District, half of them have high school education, namely 10 people (31.2\%).

The level of education is closely related to knowledge, the higher the level of parental knowledge, the higher the mother's knowledge of a problem. Parents who have a high school education level are sufficiently able to receive a variety of outside information about nutrition, children's health, child care methods and so on which can be obtained from schools or other media sources such as television, health magazines, counseling, and health workers. The health information about nutrition can 
increase individual knowledge which in turn can provide the best nutritional intake for their children.

A small proportion of toddlers at Posyandu Sumur Nangka, Suwaan Village, Modung District had a good nutritional status. This can be caused by that preschool children are still very dependent on their caregivers, so the food given will tend to be the same as the caregivers. If the food menu served by the family meets the nutritional needs of the child, the child will also grow normally.

Employment status also has an indirect effect on nutritional status. Job description can be achieved by working parents. The results of the study show that the work of mothers under five at the Sumur Nangka Posyandu, Modung District, most of them work as farmers, namely 20 people $(62.5 \%)$

Working parents, especially mothers, will have less time to pay attention to the development and the nutritional status of their children, because work is generally an activity that can take up time. Mothers who work as farmers have more time and opportunities than mothers who work outside the home such as private employees, civil servants, honorary employees, and so on.

The malnutrition status is caused by nutrient intake from insufficient food and wrong and irregular eating patterns, while good nutritional status was likely to be due to more food intake. The food needs that are fulfilled in the family will ensure food intake for family members, with the fulfillment of food intake it is hoped that the nutritional intake of the family will be fulfilled, especially children's nutrition. Good nutritional intake will make toddlers have a good nutritional.

Children who have low nutritional status (91.6\%), have a history of infectious diseases, 8 children (100\%) have good nutrition, do not have a history of infection, 2 children (8.3\%) have overnutrition, have a history of infection and a total of 24 children (99.9\%) have a history of infectious diseases.

Based on the Lambda statistical test, the relationship between history of infectious disease and nutritional status in children under five, the $P$ value is smaller than the significant value $p=0.003<\alpha$ (0.05), so Ho is rejected H1 is accepted. This means that there was a relationship between the infection diseases history and the nutritional status of children under five at Posyandu Sumur Nangka, Suwaan Village, Modung District. Based on the table interpretation, the results of the $r$ value show that the value of $r$ is (0.583), so that the correlation between the two variables can be said to be strong.

Irawati (2007) stated that infection is a disease that often occurs in toddlers, where one of the causes of infection is the lack of nutritional status of toddlers, which is directly influenced by the mother's lack of knowledge, especially about nutritious food.

Nutritional adequacy in children will increase resistance to disease. Children who experience malnutrition will be susceptible to disease, especially infection diseases. As we know, the relationship between infection and nutritional status is very close, and vice versa (Rusilanti, 2006).

Another study also showed the same results, for example a study with the title the relationship between the history of infectious diseases and the nutritional status of toddlers in Mopusi Village, Lolayan District, Bolaang Mongondow Regency by Anjani (2013) which showed that the history of infectious diseases was related to nutritional status using Spearman's Rank with cross sectional approach obtained a history of infectious disease with a malnutrition status according to age occurred in $66.7 \%$ of respondents, while a history of infectious disease with a normal nutritional status was not suitable for only $32.8 \%$ of respondents and obtained a significant value of $p=0.01$ or $p<0.05$, which means that there was a significant relationship between the infectious diseases history and the nutritional status of preschool children.

As described above, the results of this study indicated that the infectious diseases history was related to the nutritional status of preschool children. Inadequate nutritional status caused children are susceptible to disease because of poor immunity, so that the child is susceptible to disease. Good nutritional status in preschool children could lead to a good immunity and will make the body defend itself from pathogens that cause infection.

Therefore, the family must pay attention to the food consumption and the nutritional content in it, so that children can get good nutrition for the process of growing and developing. Meanwhile, children with good nutritional status must maintain their food intake and nutritional content in it. So that the nutritional status of the child is controlled and the process of growth and development is good.

The assumption of researchers is that the malnutrition status experienced by children under five is due to a history of infectious diseases, which is a serious problem that must be faced by parents. This showed that there is a history of infectious diseases found in under-five mothers where toddlers have experienced upper infections in the respiratory tract called ISPA, besides that there has been an infection in the digestive tract that triggers tuberculosis.

Inadequate nutrition is a problem that needs serious handling. Various efforts have been made by the government, including the Posyandu revitalization in increasing the coverage of weighing preschool children, counseling and mentoring, providing vitamins, increasing access, quality of malnutrition in hospital care in puskesmas, training for community members who do not work or as housewives for the cost of daily life.

\section{CONCLUSION}

Based on the results discussion of the research on the relationship between the history of infectious diseases and the nutritional status of children under 
five at Posyandu Sumur Nangka, Suwaan Village, Modung District. It can be concluded that most of toddlers at Posyandu Sumur Nangka, Suwaan Village, Modung District, had an infectious diseases history in the last three months (24 toddlers). There was a relationship between the infectious diseases history and nutritional status of children under five at the Sumur Nangka Posyandu, Suwaan Village, Modung District with $\mathrm{p}=0.003(\mathrm{p}<\alpha)$.

\section{REFERENCES}

Almatsier. (2009). Prinsip Asar Ilmu Gizi. Jakarta: Gramedia.

Apriadji, W. H. (2010). Gizi Keluarga . Jakarta: Penebar Swadaya Anggota IKPAI.

Dinkes, P. J. (2009). Program Perbaikan Gizi.

FKMUI. (2009). Gizi Dan Masyarakat. Jakarta: Raja Grafindo Persada.

FKUI. (2010). Buku Kuliah Ilmu Kesehatan Anak. Jakarta: Infomedika.

Harrry. (2010). Gizi Keluarga. Jakarta: Penebar Swadaya Anggota IKPAI.

Hidayat. (2010). Riset Keperawatan Dan Teknik Penulisan Ilmiah . Jakarta: Salemba Medika.

Irawati Y. (2007). Hubungan Antara Riwayat Penyakit Infeksi Dan Pengetahuan Gizi Balita Di Puskesmas Jatibarang Brebes.Semarang : Universitas Muhammadiyah Semarang.

Kartika. (2011). Kesehatan Balita . Jakarta: Salemba Medika.

Lanoh. (2015). Hubungan Pemanfaatan Posyandu Dengan Status Gizi Balita Di Wilayah Kerja Puskesmas Ranotana Weru Kota Manado. Jurnal Keperawatan.

Lisdiana. (2010). Waspada Terhadap Kelebihan Dan Kekurangan Gizi. Ungaran : Trubus Agriwdya.

Mita. (2010). Menjaga Kesehatan Balita. Jakarta: Puspa Swara.

Notoatmojdo. (2010). Metode Peneltian Kesehatan, Edisi Revisi. Jakarta: Rineka Cipta.

Nursalam. (2011). Konsep Dan Penerapan Metodologi Penelitian Ilmu Keperawatan Pedoman Skipsi, Tesis Dan Instrumen Penelitian. Jakarta: Salemba Medika.

Pangan, B. K. (2013). Data Status Gizi Balita Provinsi Jawa Timur.

Pudjiadi. (2009). Ilmu Gizi Klinis Pada Anak. Jakarta: Balai Penerbit Fakultas Kedokteran Universitas Indonesia.

Purwati, E. (2016). Hubungan Pekerjaan Pengetahuan. Fakultas Ilmu Kesehatan.
Proverawati, A. (2009). Buku Ajar Gizi Untuk Kebidanan. Nuha Medika : Yogyakarta.

Rahayu. (2017). Hubungan Tingkat Pengetahuan Kader Tentang Pengukuran Antropometri Dengan Keterampilan Dalam Melakukan Pengukuran Pertumbuhan Balita Di Posyandu Kelurahan Karang Asem Kecamatan Laweyan. Jurnal Ners.

RI, D. (2008). Program Gizi Makro. Jakarta: Direktorat Jendral Bina Kesehatan Masyarakat.

RI, D. (2008). Program Gizi Makro.

Rusilanti. (2006). Menu Sehat Untuk Balita. Kawan Pustaka : Jakarta.

Sembiring, N. (2004). Posyandu Sebagai Saran Peran Serta Masyarakat Dalam Usaha Peningkatan Kesehatan Masyarakat . Digitized By USU Digital Library.

Soetjiningsih. (2009). Ilmu Keperawatan Anak.Jakarta: EGC.

Sugiono. (2009). Metode Penelitian Kesehatan. Jakarta: Rineka Cipta.

Supariasa. (2010). Penilaian Gizi.Jakarta: EGC.

Supariasa, I Dewa Nyoma, Dkk. (2016). Penilaian Status Gizi. Buku Kedokteran EGC : Jakarta.

Toad, L. S. (2014). Faktor Faktor Yang Berhubungan Dengan Kunjungan Balita Di Posyandu Kelurahan Karondoran Kecamatan Ranowulu Kota Bitung. Jurnal Ilmiah Bidan.

Triwahyudianingsih. (2009). Hubungan Antara Sikap Ibu Balita Terhadap Keaktifan Dalam Kegiatan Posyandu III Dusun Boto Kabupaten Tulungagung. Doctoral Dissertation, Universitas Sebelas Maret Dalam Iskandar 2009.

Triwahyudianingsih. (2009). Hubungan Antara Sikap Ibu Balita Terhadap Keaktifan Dalam Kegiatan Posyandu III Dusun Boto Kabupaten Tulungagung. Doctoral Dissertation, Universitas Negeri Sebelas Maret Dalam Ridha 2008.

Triwahyudianingsih. (2009). Hubungan Antara Sikap Ibu Balita Terhadap Keaktifan Dalam Kegiatan Posyandu III Dusun Boto Kabupaten Tulungagung Dalam Ridha 2008. Doctoral Dissertation.

Wati. (2014). Faktor-Faktor Yang Mempengaruhi Minat Ibu Terhadap Kunjungan Ke Posyandu Di Kelurahan Kembang-Arum Kota Semarang. Skripsi. STIKES Ngudi Waluyo Ungaran.

Yogiswara, B. A. (2011). Hubungan Antara Tingkat Partisipasi Ibu Di Posyandu Dengan Status Gizi Balita . Doctoral Dissertation, Faculty of Medicine. 